\title{
The Process of Designing the Post-Mining Land Reclamation Investment Using Process Maps. Case Study
}

\author{
Katarzyna Midor ${ }^{1}$, Witold Biały ${ }^{1}$, Joanna Rogala-Rojek ${ }^{2, * \mathbb{D}}$ and Piotr Matusiak ${ }^{2}$ (D) \\ 1 Faculty of Organization and Management, Silesian University of Technology, Roosevelta 26, \\ 41-800 Zabrze, Poland; katarzyna.midor@polsl.pl (K.M.); wbialy@polsl.pl (W.B.) \\ 2 KOMAG Institute of Mining Technology, Pszczyńska 37, 44-101 Gliwice, Poland; pmatusiak@komag.eu \\ * Correspondence: jrogala@komag.eu
}

Citation: Midor, K.; Biały, W.; Rogala-Rojek, J.; Matusiak, P. The Process of Designing the Post-Mining Land Reclamation Investment Using Process Maps. Case Study. Energies 2021, 14, 5429. https://doi.org/ 10.3390/en14175429

Academic Editor: Francisco Manzano Agugliaro

Received: 30 June 2021

Accepted: 29 August 2021

Published: 31 August 2021

Publisher's Note: MDPI stays neutral with regard to jurisdictional claims in published maps and institutional affiliations.

Copyright: (c) 2021 by the authors. Licensee MDPI, Basel, Switzerland. This article is an open access article distributed under the terms and conditions of the Creative Commons Attribution (CC BY) license (https:// creativecommons.org/licenses/by/ $4.0 /)$.

\begin{abstract}
In the present day, Europe is moving away from fossil fuels. This is due to the need to reduce $\mathrm{CO}_{2}$ emissions released to the atmosphere. As a result of this process, especially in Upper Silesia, Poland, there will be more areas requiring measures after the closing of mines. Reclamation of post-mining areas is a very difficult task, as there is no universal method of planning the recultivation. During mining operations, we observed many forms of environmental degradation. The article presents the use of one of the newer and increasingly used modeling methods in recultivation processes - the process map. Analysis of the investment is presented, based on the example of the recultivation of a pit after closing the hard coal mine. The main purpose of the analysis was to shorten the designing time of the construction and realization process. Two maps of processes were made, and a map of the existing and desired processes, as well as the benefits from this, are shown. This article presents only one of the stages of the recultivation process-the investment project process-, treating it as an example for optimizing the entire project related to recultivation.
\end{abstract}

Keywords: post-mining areas; reclamation; process map; recultivation

\section{Introduction}

Mining activities in Upper Silesia (both on the Polish and Czech sides) are coming to an end, which is associated with the need to reduce $\mathrm{CO}_{2}$ emissions released into the atmosphere. The last mines in Poland are planned to be closed in 2049 [1]. The mines have always occupied a large area, so leaving these areas untouched, when mining operations are over, generates high costs. Most often, the owners of these areas are the authorities of the communes where they are located, therefore a very important issue is to recultivate the post-mining areas.

The condition for the development of an appropriate land development concept in the reclamation process is its proper recognition. This assessment can only be made by specialized staff who skilfully combine all aspects related to reclamation. In order to correctly assess the possibilities of the analysed post-mining area, it is necessary to prepare a feasibility study, including both the comprehensive solution and its components. It is advisable to determine not only the division of the area in terms of future and expected functions, but also to create a list of stages of implementation of the entire project, taking into account the time horizon. To develop a plan and project for the transformation of an area degraded by mining activities, it is necessary to analyse its transformation possibilities, which include both external and internal factors. The external factors include the possibilities of land development, while the internal factors include the properties of the land, determining its susceptibility to transformations.

Process management, the essence of which consists of planning processes as cycles of each activity and capturing "critical moments" in them, i.e., those in which the process may be disrupted and its goal may not be achieved, is a useful instrument supporting the recultivation process. Mapping of the process is an important element of the process 
management. In this article, the authors presented (attempted) the use of the modeling method in recultivation processes using a process map.

\section{Materials and Methods}

Presentation of the possibilities of using the map of processes at the stage of planning an investment related to the recultivation of post-mining land is this article's objective. The case study to which the process map was applied concerns the area in which mining activities were terminated.

The main purpose of the analysis was to shorten the time of the recultivation planning and realization. As part of the analysis of the possibility of reducing this time, two maps of processes were made: a map of the existing and desired state processes, and the benefits obtained on this account were shown.

The testing methods used in the article were the following:

1. Analysis of the existing conditions on the basis of the collected documentation;

2. Application of the process map to describe the activities that were undertaken when planning the investment-the heap recultivation and the existing conditions;

3. Critical analysis of the obtained image of the real situation and, on its basis, suggesting improvements to the activities to shorten the investment implementation timeprocess map and the desired state;

4. Development of Gantt charts for the existing and desired state on the basis of the created process maps, which allows those involved to determine the implementation time of the preparation and realization of the investment.

\section{Literature Review}

In today's entrepreneurial world, investment-related processes have a significant role. Every manufacturing company (and not only), in order to function on the market in a way that allows the achievement of benefits, is forced to invest in development. However, pro-development investments alone are not enough. Increasingly, attention has been paid not only to the high quality of products or services that make life easier $[2,3]$, but also to the state of the environment in which we live [4-7]. In the current reality, in order to achieve a competitive position on the market, companies must calculate the expenses incurred for environmental protection in the costs of their activities. These expenditures are most often related to environmental investments, carried out to meet the requirements set by, among others, the state authorities for the protection of ecosystems and thus human health. Conservation investments must become an integral part of comprehensive investment programs, regardless of their nature [8,9]. The increase in investment in the field of environmental protection is necessary due to ecological threats [10].

Until the end of the last century, the area of the Silesian Province was dominated by the mining industry, mainly deep coal mines. In the 21st century, there is a sudden retreat from coal, the mines are being closed, and the areas where coal was once mined need to be restored. The reclamation process, aimed at restoring these areas and giving them the possibility of re-use, is reclamation taking into account economic [10-12], geologicalengineering, and natural, etc., [13-15] aspects.

Reclamation is understood as: "the process of restoring land damaged (degraded) by human activity to its original form or to use and natural values as close to the natural state as possible" [16].

This paper presents the process of creating investment projects through an example of the reclamation of a pit after an unused underground mining plant. To create the model, the method of so-called process maps was used. This method allows for a clear characterization of the course of action during project implementation.

\subsection{Reclamation}

Environmental investments are related to two fields:

1. Environmental engineering; 


\section{Environmental protection.}

Environmental engineering is a scientific and technical field that includes the protection and shaping of the natural environment by technical methods. Its main task is to design and create new technologies, the use of which in various fields will reduce the negative impact of man on the environment.

Environmental protection, within the meaning of the Environmental Protection Law [17], is to undertake or abandon activities that enable us to maintain or restore the balance of nature.

In particular, this includes:

1. Rational shaping of the environment and management of resources, in accordance with the principle of sustainable development;

2. Counteracting pollution;

3. Restoring natural elements to their proper state.

Environmental protection requires wide, integrated knowledge, creative inventiveness, and ethical attitudes, taking into account not only the good of people living today but also the good of future generations. This should be taken into account in the design and manufacture of technical equipment and in any industrial activity. Therefore, minerals should be exploited in a way that limits the damage done to the environment, and the reclamation of areas after the exploitation should restore the natural elements of the environment to their proper condition.

Reclamation is one of the methods of environmental protection, although it is more related to removing effects than preventing them. Reclamation consists in restoring the usable value to the land by performing technical, biological, or agrotechnical procedures $[9,10,14,18]$. However, it applies only to those areas that have been degraded as a result of anthropogenic activity or natural disasters. Often wrongly, the reclamation of e.g., marshes, ponds, etc., or wastelands in general, have been referred to.

Reclamation of an "ecological wasteland" (it functions in nature) may take place only in exceptional cases concerning, e.g., the use of an area for specific purposes necessary for civilization functioning. The areas subject to reclamation include, among others, lands devastated by industry and mining, waste dumps, heaps, pits, etc. Therefore, the reclamation process should become one of the elements of revitalization popular nowadays, the aim of which is to rebuild destroyed, but once living, urban areas. Reclaimed areas should then be rationally managed. Reclamation and management are interrelated procedures. The type of reclamation depends on the development direction - the planned development direction implies the reclamation technology. Rehabilitation of reclaimed area is based on the execution of appropriate measures, enabling the use of the land for agricultural, forestry, or recreational purposes, for example.

The basic task of reclamation is to create favorable conditions for the development of biological processes in the top layer of dumps or excavations, to regulate air-water relations, to neutralize the existing toxicity of formations, and to give the surface a shape convenient for conducting the planned works $[5,8]$.

Therefore, basically two stages are distinguished:

1. Basic (technical) reclamation - the aim of which is to form an area and prepare the top layer of the reclaimed area for restoration of a layer of soil with established properties, or soil with features suitable for the implementation of, e.g., construction, recreational facilities, or others;

2. Detailed (biological) - fertilization of the topsoil layer with such means as to create a suitable environment for the development of vegetation and thus also animals, and the planting of appropriate crops.

Each reclamation process, in order to be carried out properly, must consist of these two stages. At each of these stages, in order to facilitate them, studies and experience from other projects of this type should be used $[2,3,6,7]$. 
As environmental protection activities do not have a very long-standing tradition in Poland, some activities undertaken to reclaim areas, mainly mining areas, are often casual and without a concrete scientific and exploratory basis.

Taking into account the previous experience of the reclamation process, both in theoretical and practical work, the basic and detailed reclamation can be divided into the following stages:

1. Collection, gathering, and selection of information on damaged land;

2. Programming of reclamation works, taking into account the direction of area development;

3. Development of a reclamation project for a specific site;

4. Preparation of cost estimate;

5. Project implementation;

6. Development of the reclaimed area;

7. Evaluation of facts.

\subsection{Legal Acts on Reclamation Binding in EU and Poland}

The reclamation of degraded land is regulated by law and most often remains the responsibility of the investor. International laws and management plans are created to stop degradation. Moreover, in our country, a legal system for environmental protection and reclamation has been created and is still under development. There are also appropriate authorities supervising compliance with these laws.

In the field of mining exploitation, environmental protection, and reclamation, there are two authorities:

- Higher Mining Office, along with district mining offices;

- The State Inspectorate for Environmental Protection, along with its respective branches.

In recent years, many new legal acts have been published, or they contain standards related to new conditions, including those resulting from Poland's participation in the European Union.

Legal acts that regulate the reclamation of mining areas in a direct, indirect, or significant manner include:

1. Geological and Mining Law (Act of 4.02.1994, Journal of Laws no. 273 of 2004, item 2703) [19];

2. Act on protection of agricultural and forest land (Journal of Laws of 2017, item 1161) [20];

3. Environmental Protection Law (Journal of Laws 2001, no. 62, item 627) [17];

4. Act on real estate management (Journal of Laws of 2018, item 2204) [21];

5. Act on spatial planning and development (Journal of Laws 80 of 2008, item 1945) [22];

6. Act on revitalization (Journal of Laws 2018, item 1398) [23];

7. Regulation of the Minister of Environmental Protection and Forestry of 14 July 1998 on determining the types of investments that are particularly harmful to the environment and human health or that may deteriorate the environment, and the requirements to be met by environmental impact assessments of such investments (Journal of Laws no. 93 of 1998, item 589) [24];

8. Regulation of the Minister of Environmental Protection and Forestry on the requirements which should be met by a forecast of the effects of local spatial development plan arrangements on the natural environment (Journal of Laws, 2002, no, 197 item 1667) [25];

9. ISO 9000 International Standards;

10. Water Law (Dz. U. 2017 poz. 1566) [26];

11. Construction Law (Dz. U. 2020 poz. 2127) [27].

\subsection{Modeling the Reclamation Process Using Process Maps}

The literature provides many methods of representing (modeling) systems and the processes occurring in them [28-30]. With the use of appropriate modeling methods, it 
is possible to improve the quality and reduce the time and costs of projects. The number and universality of some modeling methods allows their application in both processes and structures (organizational, information, decision-making, etc.).

In order to develop a model of the reclamation investment process, one of the modeling methods was selected. This method is known as the process map. A very important advantage of this method is that it becomes increasingly used in tasks related to improving the efficiency of specific activities in various types of processes. This method also allows for a clear presentation of the inputs and outputs of this process and a reflection of the connections between given elements and an easier interpretation of possible malfunctions [28].

The "process mapping" method is based on the assumption that:

1. Any sequence of activities implemented in a given structure/organization can be considered as an information flow system;

2. Process design is consistent with the task of information system design;

3. Comprehensive information system design should be multi-level.

Development of a process map consists of the following stages [31]:

1. Inventory of the organizational structure-recognition of the structure of entities responsible for the development of the reclamation project;

2. Identification of processes-identification of all processes and their hierarchy of importance;

3. Selection of the modeled process-distinguishing from the whole the element that will be represented by a map;

4. Analysis of the modeled process-identification of discontinuities;

5. Development of elimination methods regarding discontinuities.

Time is associated with the notion of process, but it is not a limitation if we can describe it by means of a map. The process map can effectively describe processes of two types:

1. Closed processes, which are characterized by, among other things, a definite starting and ending (destination) point and a finite duration;

2. Open processes, which can be interpreted in terms of the routine functions of a given organization.

By creating a map (or process maps) for a given organization/system, taking into account the three levels of organization, process, and workplace, it is possible to model the organization's functions in the specific tasks of this organization.

Process maps are a very useful tool when introducing changes and assessing the efficiency of the functioning enterprise. A graphic representation of all activities and their mutual relations is much easier to understand and analyse than a verbal description. At the same time, the advantage of process maps is the fact that they do not present a static image of the company (as in the case of organization charts), but rather its dynamic side.

\section{Results}

The article presents a model of an investment related to the reclamation of postmining areas after a closed mining plant 31]. This area is a waste dump created as a result of the underground exploitation of minerals. This heap, for the most part, consists of carboniferous shales. The direction indicated by the investor after the reclamation is completed assumes land development.

The modeling method was adopted using the process map. Its advantage is a clear representation of all the inputs and outputs of a given process in a graphic form, as well as a depiction of the relations between its individual elements. Thanks to this method, it is possible to easily observe who performs what and for how long, as well as to accurately interpret possible inefficiencies.

Based on the project documentation and the environmental interview, a thorough analysis of the different stages of a reclamation project, as well as the entities involved in them, was carried out. 
The chosen method allows for a clear characterization of the course of action in the implementation of this type of project. This characterization, in turn, allows for a precise interpretation of the irregularities in the process of creating reclamation projects of postmining excavations and the introduction of necessary changes. Thanks to them, the time needed to develop the reclamation project and to collect the necessary documentation was significantly shortened.

The application of a process map allowed for an accurate and precise presentation of both the entire process of designing an investment project related to the reclamation of post-mining areas and its selected fragment. After the analysis of the whole process map, it was decided that the element in which the biggest changes should be made was the stage of creating the construction and executive project. The process maps were also drawn up for this stage.

Process map-the existing state

Process map of the existing state (Figure 1) shows how the construction and execution project was carried out.

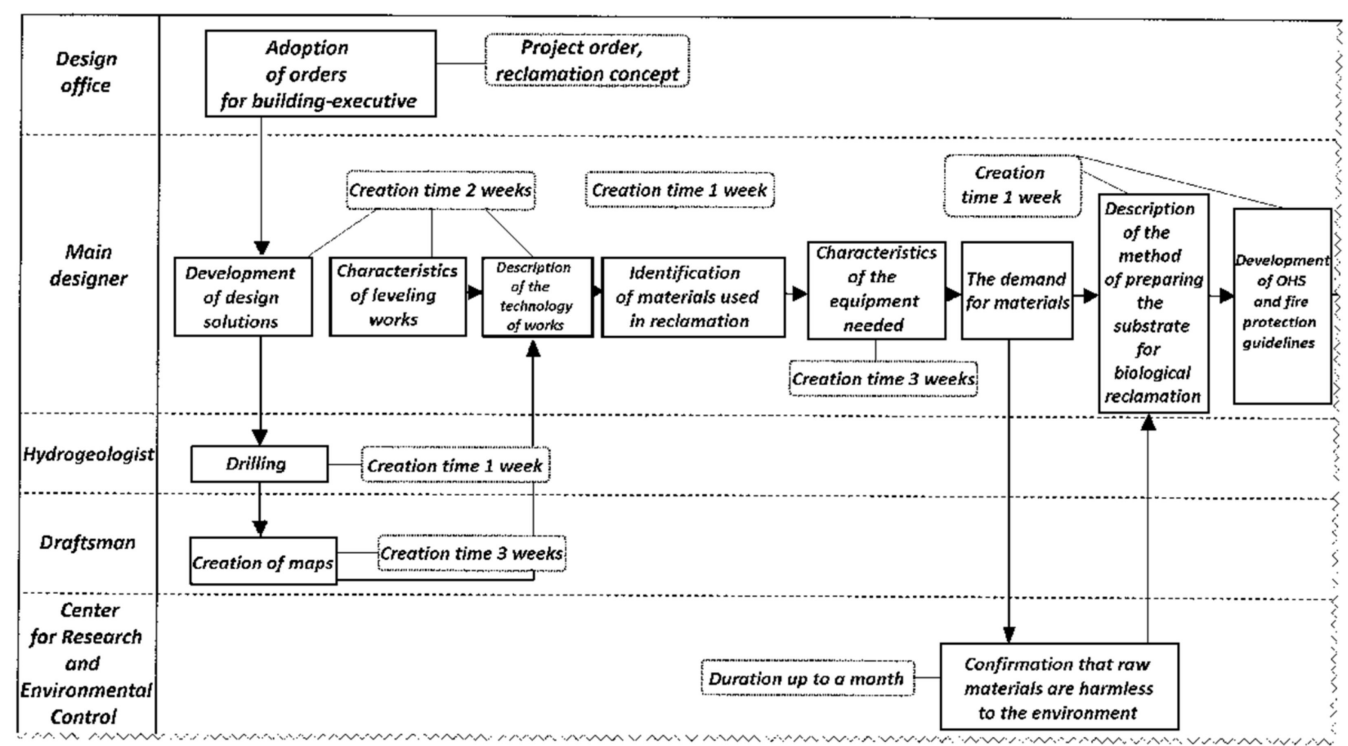

Figure 1. Process map for the construction and execution project-the existing state.

Eight entities taking part in the process are distinguished here, and the order of performed activities and the time of their performance are specified. Due to its size, only the basic fragment of the map was placed.

Preparation of process map allowed those involved to identify all possible irregularities or delays occurring in this process and affecting the extension of its implementation time. The choice of this fragment of the map was determined by the fact that the most irregularities were noticed in this part, and proposed improvements significantly influenced the shortening of time of the whole project process.

\section{Process map-the desired state}

Based on the detailed analysis of the above fragment from process map of the existing state (Figure 1), the following conclusions have been drawn for the construction and execution project stage:

When preparing the maps, it is necessary to wait for the results of hydrogeological measurements. In fact, taking hydrogeological measurements and mapping can be conducted at the same time because maps are made first, which does not use information from drilling. This can shorten the process by a week.

The construction and detailed design is not submitted for reconciliation until it is completed. As each part of the project is analysed separately by authorized persons, the project can be "sent" for agreement after the characteristics of the required equipment have 
been drawn up. As a result, the time required for approval after project completion will be significantly reduced.

For each reclamation project, it is necessary to prepare an environmental assessment of the materials used for reclamation. Such an analysis takes about a month and is commissioned in the middle stage of design work. If the analysis is commissioned as soon as the design work begins, the duration of the entire project cycle can be reduced by up to one month.

Changes proposed for implementation during the project development phase were presented below in the form of a process map of the desired state (Figure 2).

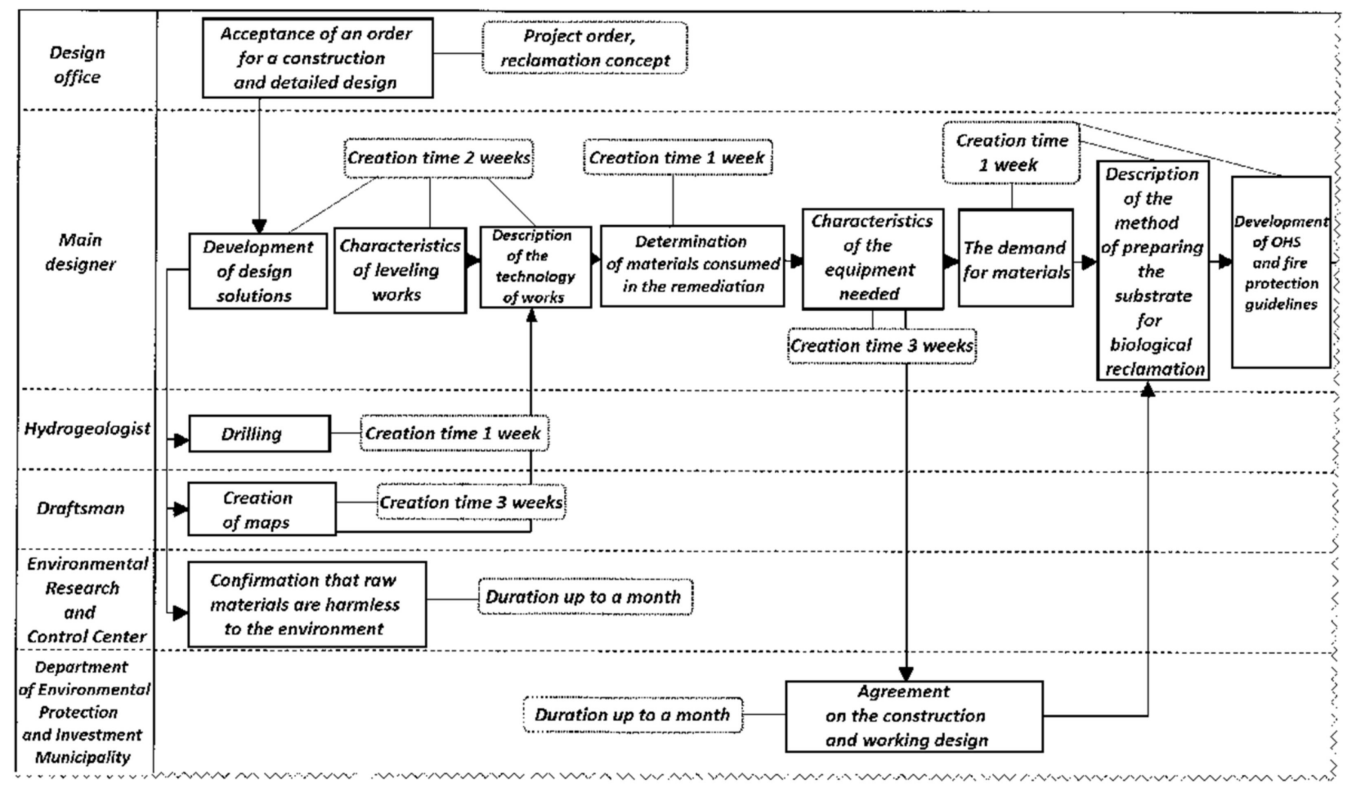

Figure 2. Process map for the construction and execution project-the desired state.

The presented process of drawing up the process map enables those involved to understand what changes need to be made, at what stages, and by how much the duration of the whole stage will be shortened.

The Gantt charts (Figures 3 and 4) show the time (in weeks) for the implementation of reclamation plans, which were made on the basis of the process maps shown in Figures 1 and 2.

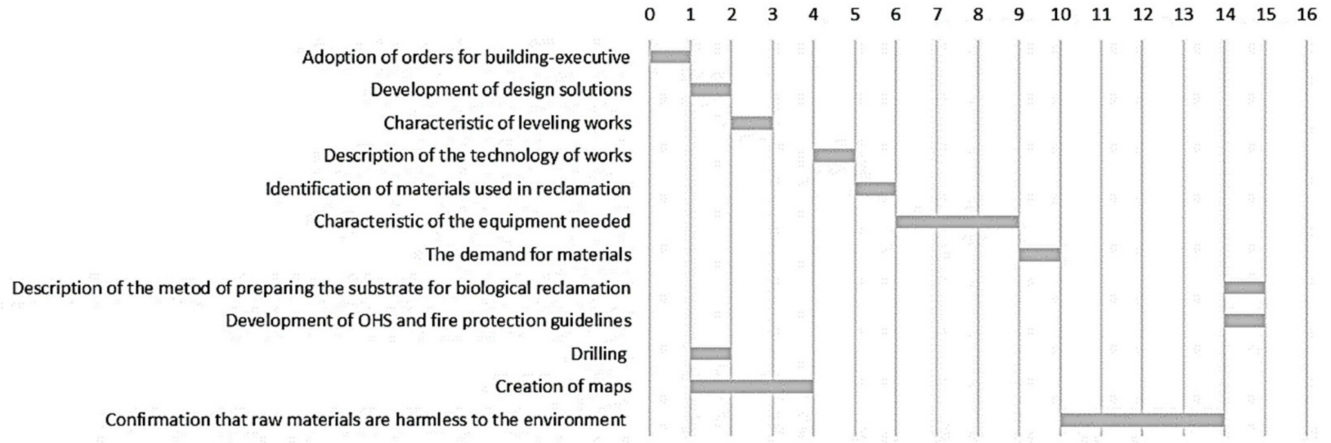

Figure 3. A Gantt chart showing the time needed to prepare a construction and executive project for the reclamation of the heap-the current state.

Figure 3 shows the time needed to complete the construction and the executive design for the reclamation of the heap for the existing condition, which was 15 weeks. On the other hand, Figure 4 presents a Gantt chart relating to the map of the desired state processes. A comparison of these two charts shows that the duration of the construction project executive has decreased by 5 weeks, which is reflected in the improvement of the efficiency 
of remediation of the site. In addition, the presentation of the project planning of this investment using the Gantt chart allows one to clearly identify the sequence and time of the commencement of the individual tasks, which decisively improves the efficiency of conducting investment projects.

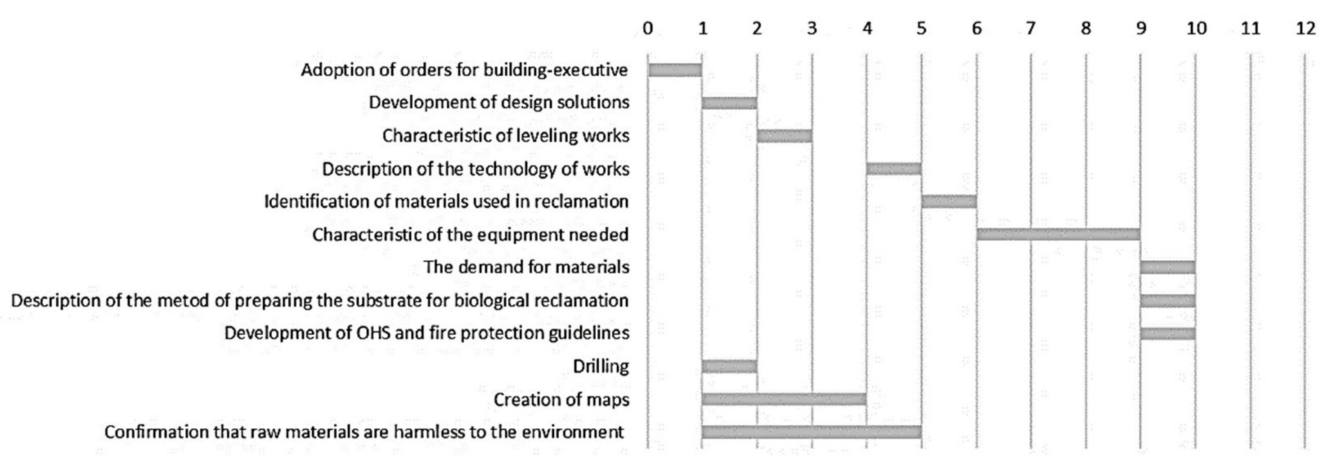

Figure 4. A Gantt chart showing the time needed to prepare a construction and executive design for the reclamation of the heap-desired condition.

\section{Conclusions}

Process management improves the effectiveness of functioning. Scheduled processes affect the integration of divisions and organizational units, increasing the transparency of the entire organizational structure as a result of the clear segregation of duties and responsibilities. Use of the process map as process management for the planning and realization of an investment related to the recultivation of the post-mining area allowed for an accurate and transparent presentation of both the entire investment planning process related to the recultivation of post-mining areas, as well as a specific, selected part of it. After analysing the map of the entire process, it was found that the element in which the greatest changes can be made was the stage of creating the plan for investment realization. The map of the existing conditions of the processes for this stage prepared with this method and the conclusions drawn on its basis allowed for the development of a map of the required processes. Thanks to these changes, the project development time, assuming that all agreements are positive, was reduced by five weeks. Shorter implementation time of the project also allows for a reduction in its costs, and the precise arrangement of each activity enables the improvement of the quality of their realization.

The projects concerning the reclamation of post-mining areas in the Silesian Voivodeship were analysed. The developed model of the map of the processes of creating the detailed design can be considered universal in the case of the recultivation of other postmining areas in this region. Comparisons of the detailed investment designs show that the process of their creation is identical. The solutions presented above relate only to the duration of the designing stage. In the analysed case, circulation of documents was reduced to a minimum due to the small number of people involved in the development of the detailed investment design.

To shorten the time between the decision on recultivation and its commencement, changes should also be made at other stages of the investment design. Moreover, the state administration institutions are the participants of this process, where the investor has no chance to shorten the time for making a decision.

This article presents only one of the stages of the recultivation process-the investment project process, treating it as an example of optimizing the entire recultivation project. The analysis showed that, by using the process map method, it is possible to shorten each of the stages of the recultivation.

Author Contributions: Conceptualization, W.B. and K.M.; methodology, K.M.; validation, W.B., P.M. and J.R.-R.; formal analysis, P.M.; writing-original draft preparation, K.M. All authors have read and agreed to the published version of the manuscript. 
Funding: The article was written in support of BK-273/ROZ3/2021 (13/030/BK_21/0065) research under the title "Department of Production Engineering' resources development for carrying out activities in the areas related to the Silesian University of Technology Priority Research Areas".

Institutional Review Board Statement: Not applicable.

Informed Consent Statement: Not applicable.

Data Availability Statement: Data sharing not applicable.

Conflicts of Interest: The authors declare no conflict of interest.

\section{References}

1. Poland's Last Coal Mine is Due to Cease Operations in 2049. Available online: https://alebank.pl/ostatnia-kopalnia-weglakamiennego-w-polsce-ma-zakonczyc-dzialalnosc-w-2049-r/ ?id=342990\&catid=27735 (accessed on 18 May 2021).

2. Skousen, J.; Zippe, C. Post-mining policies and practices in the Eastern USA coal region. Int. J. Coal Sci. Technol. 2014, 1, 135-151. [CrossRef]

3. Dyczkowska, J.; Bulhakova, Y.; Łukaszczyk, Z.; Maryniak, A. Waste Management as an Element of the Creation of a Closed Loop of Supply Chains on the Example of Mining and Extractive Industry. Manag. Syst. Prod. Eng. 2020, 28, 60-69. [CrossRef]

4. Lapčik, V.; Kohut, O.; Novák, P.; Kaločajová, A. Wpływ eksploatacji górniczej surowców na środowisko. Inżynieria Miner. J. Pol. Mineral Eng. Soc. 2018, 2, 265-272. [CrossRef]

5. Lintukangas, M.; Suihkonen, A.; Salomaki, P.; Selonen, O. Post-mining solutions for natural stone quarries. J. Min. Sci. 2012, 48, 123-134. [CrossRef]

6. Łacny, Z.; Kowalska, N.; Tran, L. The Possibilities of the Revitalization of Post-Mining Areas-the Polish and Vietnamese Examples. Inżynieria Miner. J. Pol. Mineral Eng. Soc. 2019, 2, 7-13. [CrossRef]

7. Parrotta, J.A.; Knowles, O.H. Restoring tropical forests on lands mined for bauxite: Examples from the Brazilian Amazon. Ecol. Eng. 2001, 17, 219-239. [CrossRef]

8. Lima, A.T.; Mitchell, K.; O'Connell, D.W.; Verhoeven, J.; Cappellen, P. The legacy of surface mining: Remediation, restoration, reclamation and rehabilitation. Environ. Sci. Policy 2016, 66, 227-233. [CrossRef]

9. Santarius, P.; Białecka, B.; Grabowski, J. Środowiskowe i gospodarcze problemy spowodowane degradacja terenów w Górnośląskim Zagłębiu Węglowym. Pr. Nauk. GIG Górnictwo Sr. 2007, 1, 85-100.

10. Wytyczne w Zakresie Rewitalizacji w Programach Operacyjnych na Lata 2014-2020. Available online: http:/www. funduszeeuropejskie.gov.pl/ (accessed on 4 August 2020).

11. Frankowski, Z.; Godlewski, T.; Irmiński, W.; Łukasik, S.; Majer, E.; Nałęcz, T.; Sokołowska, M.; Wołkowicz, W.; Chada, K.; Choromański, D.; et al. Zasady Dokumentowania Warunków Geologiczno-Inżynierskich dla Potrzeb Rekultywacji Terenów Zdegradowanych; Państwowy Instytut Geologiczny: Warszawa, Poland, 2012; pp. 29-41. ISBN 978-83-7863-090-6.

12. Kasztelewicz, Z. Ekonomiczna rekultywacja i rewitalizacja terenów pogórniczych. Kopaliny 2012, 1, 16-20.

13. Kobylańska, M.; Gawor, Ł. Problematyka przeobrażeń przestrzennych w procesach rewitalizacji terenów poprzemysłowych. Pr. Kom. Geogr. Przemystu Pol. Tow. Geogr. 2017, 31, 68-80. [CrossRef]

14. Ostręga, A.; Uberman, R. Kierunki rekultywacji i zagospodarowania-sposób wyboru, klasyfikacja i przykłady. Górnictwo Geoinżynieria 2010, 34, 445-461.

15. Paulo, A. Przyrodnicze ograniczenia wyboru kierunku zagospodarowania terenów pogórniczych. Gospod. Surowcami Miner. Mineral. Resour. Manag. 2008, 24, 9-40.

16. Ekoleksykon. Internetowy Leksykon Ekologii i Ochrony Środowiska. Available online: https://www.ekologia.pl/wiedza/ slowniki/leksykon-ekologii-i-ochrony-srodowiska/rekultywacja (accessed on 17 August 2020).

17. Prawo ochrony środowiska, (Dz. U. 2001 r., nr 62 poz. 627).

18. Maciejewska, A. Rekultywacja I Ochrona Środowiska W Górnictwie Odkrywkowym; Oficyna Wydawnicza Politechniki Warszawskiej: Warszawa, Poland, 2000.

19. Geological and mining law, (Journal of Laws No. 273 of 2004, item 2703).

20. Act on the protection of agricultural and forest land (Journal of Laws of 2017, item 1161).

21. Act on real estate management (Journal of Laws of 2018, item 2204).

22. Act on spatial planning and development (Journal of Laws of 2018, item 1945).

23. The Revitalization Act (Journal of Laws of 2018, item 1398).

24. Ordinance of the Minister of Environmental Protection, Natural Resources and Forestry of July 14, 1998 on the determination of types of investments particularly harmful to the environment and human health or likely to deteriorate the condition of the environment and the requirements to be met by environmental impact assessments for such investments. (Journal of Laws of 1998, No. 93, item 589).

25. Ordinance of the Minister of the Environment of November 14, 2002 on the detailed conditions to be met by an environmental impact forecast for draft local spatial development plans. (Journal of Laws of 2002, No. 197, item 1667).

26. Water law (Journal of Laws of 2017, item 1566).

27. Construction Law (Journal of Laws of 2020, item 2127). 
28. Kaźmierczak, J. Zastosowanie map procesów w projektowaniu systemów wspomagania zarządzania zadaniami inżynierskimi. V Szkoła Komputerowego Wspomagania Projektowania, Wytwarzania i Eksploatacji, Szczyrk, maj 2001. Przegląd Mech. 2002, 2, $27-32$.

29. Stępien, M. Selection of methods and tools for processes modeling in the area of municipal waste management. Systemy Wspomagania w Inżynierii Produkcji. Gliwice 2017, 6, 233-242.

30. Gang, X. Modeling decision processes of a green supply chain with regulation on energy saving level. Comput. Oper. Res. 2015, 54, 266-273.

31. Malik, A. Opracowanie Modelu Procesu Inwestycyjnego Na Przykładzie Rekultywacji Terenów Pogórniczych w Gminie CzerwionkaLeszczyny, Praca Magisterska; Politechnika Śląska Gliwice, Biblioteka Politechniki Śląskiej: Gliwice, Poland, 2004. 